\title{
Growth and Seasonality of Tourist Arrivals at Athirappilly-Vazhachal Ecotourism Destination
}

\author{
K. Sooraj Menon \\ Guest Faculty, Department of Commerce, Sree Vyasa N.S.S. College, Thrissur, Kerala, India \\ E-Mail: informmenon@gmail.com
}

\begin{abstract}
Ecotourism destinations can be well managed, developed and preserved only when the factors affecting their day-to-day functioning are managed efficiently and regulated through a systematic mechanism. Kerala Forest and Wildlife Department is managing the ecotourism destinations in Kerala with the help of host community participation through Participatory Forest Management (PFM). This paper explores the potential of Athirappilly-Vazhachal in terms of growth in tourist arrivals and elucidates the growth pattern of various types of tourist arrivals. The monthly seasonality of tourist arrivals is also made a part of this study so that the peak season and off season are identified. This will help in improving the management of ecotourism destinations and assigning resources (human resource, physical resources, and financial resources) so that quality tourism experience can be provided to tourists, while carrying capacity and sustainability aspects of ecotourism destination are ensured.
\end{abstract}

Keywords: Tourist Arrivals, Ecotourism Management, Seasonality, Athirappilly-Vazhachal

\section{INTRODUCTION}

Ecotourism destinations could be properly managed only when the tourism management of the destination is efficient. Tourism has the power to enhance the environment, to provide funds for conservation, to preserve culture and history, to set sustainable use limits, and to protect natural attractions. It also has the power to destroy. If tourism is not properly planned and implemented, it can destroy vegetation, create overcrowding, litter trekking areas, pollute beaches, result in overbuilding, eliminate open space, create sewage problems, cause housing problems, and ignore the needs and structure of the host community. (Weaver and Lawton, 2007)

Ecotourism studies have been conducted at state level, national level and international level so as to assess the feasibility of ecotourism projects. A study which is entirely focused on a single ecotourism destination incorporating its tourist arrivals growth pattern and seasonality of tourist arrivals were not conducted in Kerala. Athirappilly and Vazhachal, being an emerging ecotourism destination and frequently visited destination in central Kerala is selected for the purpose of study.

\section{REVIEW OF LITERATURE}

Manoj (2017) in his study "Impact of ecotourism: evidence from Thenmala ecotourism destination in Kollam district,
Kerala” studies the impact of ecotourism with reference to Thenmala in Kollam district in Kerala- the first planned ecotourism destination in India. Based on the study findings, the paper suggests strategies for sustained development of ecotourism. It studies the impact of ecotourism on the tourism spot in terms of the disturbances caused to the location as perceived by the local community and tourism officials. The study also examines the feedback of tourists regarding the response from the local people as well as the major issues and problems faced by them.

Komppula (2016) in her study "The role of different stakeholders in destination development" highlights the crucial role of individuals, entrepreneurs and other stakeholders in the development of a tourist destination during its life cycle. This paper presents a single case study in a Finnish context, the findings cannot be, and are not meant to be, generalized. Rather, the findings present an example of an exception to the mainstream destination management and governance literature.

Abraham (2015) in his research thesis "Community Participation in Ecotourism: An Inclusive Development Option for Kerala" made the inferences obtained from the study and presented in coherent area-specific levels so as to understand the ecotourism and its sub-sector areas for the researchers and policy makers about the issues, importance and potentialities of the sector. It can be drawn that environment protection and the role of ecotourism in improving the income and livelihood options of the local communities is the most important factor concerning the community members.

Ke (2012) in the research paper "The Weakness and Innovation of China Eco-tourism" proposes a new direction of eco-tourism development in China. Using the converse thinking method, it was found that China eco-tourism is still locating a lower level, and has some problems: the ecotourism plan is simple and unreasonable; the eco-tourism development has mainly focused on better ecological system resource but not the worse; the eco-tourism products mostly expense natural resource and damage ecological system, but not protect or rebuild it.

Salpekar (2009) in her book "Indian Tourism, wildlife tourism and ecotourism" provides idea on national tourism policy and action plan, dimensions and parameters of 
tourism , description and evaluation of Mohammed Yunus committee on tourism,1988. The book also gives an account on growth and structure of tourism in India. A critical analysis on recent tourism and related policies are detailed in the second chapter of the book.

Stephen Wearing and John Neil (2009) in their book "Ecotourism - Impacts, Potentials and Possibilities" analyses the impacts of mainstream tourism in developing and developed countries, and argues the benefits of adopting the philosophical approaches of ecotourism to create a more sustainable tourism industry in every country around the world. This book also explores the impact of mainstream tourism whilst analysing ecotourism concepts and principles to highlight the potential positive social and environmental benefits of ecotourism.

Hudson (1998) in his research work "Waterfalls Resources for Tourism" discusses waterfalls within the theoretical frameworks developed by economists and geographers in the field of recreation and tourism. Examples are drawn from various parts of the world, including the United States, Canada, and the United Kingdom, with Jamaica examined as a case study. Here, as in many tourism areas, although visitors usually choose their destinations for reasons other than the appeal of waterfalls, these landscape features play important roles as attractions.

Although there are large number of studies on ecotourism, the main focus of those studies were empowerment, inclusion, destination development, marketing of ecotourism and attitude and perception of ecotourists etc. The factors that are likely to affect the management of an ecotourism destination are the total tourist arrivals to the destination and the seasonality of tourist arrivals. The growth of tourist arrivals indicate the average number of tourists to the destination for a period of time and seasonality indicates the time span within which there is high tourist traffic and low tourist traffic. It will be better if the ecotourism destinations are managed and developed according to the potential of destination in terms of revenue generation and total tourist arrivals.

Based on the review of literature, it was understood that both growth of tourist arrivals and monthly seasonality of tourist arrivals were not studied at micro level in Kerala. There are studies which include growth of tourist arrivals that are focused on providing a description about tourist arrivals of the whole state at macro level. A root level destination centric study encompassing these aspects of a single ecotourism destination is not present.

\section{STATEMENT OF THE PROBLEM}

Every ecotourism destination has an identity of its own which will be totally different from that of other ecotourism destinations. There are a very large number of factors that have a bearing on the tourist traffic to an ecotourism destination which ranges from accessibility of destination to global recognition of ecotourism destinations. For the purpose of developing an ecotourism destination and optimally exploiting its potential along with conservation of it is a very daunting task. This purpose could only be served when there is a destination centric plan formulated by the managers of ecotourism destination. According to the Kerala Forest Statistics published by Kerala Forest and Wildlife Department, Athirappilly-Vazhachal ecotourism destination is ranking number one in terms of total income generated from tourism activities, total tourist arrivals, foreign tourist arrivals and domestic (adult) tourist arrivals. As this fact is very significant and there is more scope on development of this ecotourism destination it becomes very essential to know about the pattern of growth and seasonality in tourist arrivals of this ecotourism destination. This destination centric study aims to provide an elucidation on tourist arrival growth and monthly seasonality of Athirappilly-Vazhachal ecotourism destination.

\section{OBJECTIVES OF THE STUDY}

The following are the specific objectives of the study:

1. To analyse the growth of tourist arrivals to Athirappilly-Vazhachal ecotourism destination.

2. To describe the monthly seasonality of tourist arrivals to Athirappilly-Vazhachal ecotourism destination.

\section{METHODOLOGY OF THE STUDY}

The present study is descriptive in nature and secondary data were collected and used for the study. The secondary data were collected from books, published journals, annual reports of Athirappilly and Vazhachal Vana Samrakshana Samithies, daily collection statements of Athirappilly tourist ticket counter, Final plan document of $13^{\text {th }}$ five year plan of Athirappilly Grama panchayath, and Kerala forest statistics of Kerala Forest and Wildlife Department. The collected data were tabulated and analysed by using percentage analysis for the purpose of elucidating growth of tourist arrivals and monthly seasonality of tourist arrivals are described using graphical representations of tourist arrivals.

\section{ATHIRAPPILLY AND VAZHACHAL ECOTOURISM DESTINATION - A BRIEF PROFILE}

Athirappilly is a first grade Grama Panchayath with 489.00 $\mathrm{km}^{2}$ area in Chalakudy Taluk, Thrissur district in Kerala, India. It is located $60 \mathrm{~km}$ from Thrissur city, $70 \mathrm{~km}$ northeast of Kochi city, $55 \mathrm{~km}$ northeast of Cochin International Airport, and $30 \mathrm{~km}$ from Chalakudy town. The Athirappilly Falls is situated $1000 \mathrm{ft}$ above sea level on the Chalakudy River, at the entrance to the Sholayar ranges of the Western Ghats; Athirappilly is a scenic combination of forests and little streams. Falling from a height of 80 feet, this is one of the largest waterfalls in the state. Many endangered and endemic species of flora and fauna are found in the forests of the Athirappilly-Vazhachal area.

Vazhachal Falls is a rushing watercourse in the Chalakudy River in the Thrissur district of Kerala, South India. It is 
located $36 \mathrm{~km}$ from Chalakudy and $5 \mathrm{~km}$ from Athirappilly Falls. The riparian forests of the Chalakudy River have revealed the existence of a thick riparian vegetation of more than 10 metres width for a distance of $10.5 \mathrm{~km}$ downstream from Peringalkuth, covering an area of 58.5 hectares.

\section{TOURIST ARRIVALS GROWTH AT ATHIRAPPILLY - VAZHACHAL TOURISM DESTINATION}

This section provides a brief discussion about the growth of tourist arrivals at Athirappilly and Vazhachal ecotourism destination. The growth of tourist arrivals is elucidated by categorizing tourist arrivals into Domestic (Adult) Tourist Arrivals, Student Tourist Arrivals and Foreign Tourist Arrivals. The description about Total Tourist Arrivals is also mentioned.

TABle I TOURIST ARrivals To ATHIRAPPILly-VAZHACHAL TOURISM DESTINATION

\begin{tabular}{|c|c|c|c|c|c|c|c|c|c|c|}
\hline Year & $\begin{array}{c}\text { Domestic } \\
\text { Tourist } \\
\text { Arrivals } \\
\text { (Adults) }\end{array}$ & $\begin{array}{c}\text { Growth } \\
\text { Rate }\end{array}$ & $\begin{array}{c}\text { Student } \\
\text { Tourist } \\
\text { Arrivals }\end{array}$ & $\begin{array}{c}\text { Growth } \\
\text { Rate }\end{array}$ & $\begin{array}{c}\text { Total } \\
\text { Domestic } \\
\text { Tourist } \\
\text { Arrivals }\end{array}$ & $\begin{array}{c}\text { Growth } \\
\text { Rate }\end{array}$ & $\begin{array}{c}\text { Foreign } \\
\text { Tourist } \\
\text { Arrivals }\end{array}$ & $\begin{array}{c}\text { Growth } \\
\text { Rate }\end{array}$ & $\begin{array}{c}\text { Total } \\
\text { Tourist } \\
\text { Arrivals }\end{array}$ & $\begin{array}{c}\text { Growth } \\
\text { Rate }\end{array}$ \\
\hline 2006 & 449.22 & & 82.62 & & 531.84 & & - & & 531.85 & \\
\hline 2007 & 511.64 & 13.89 & 80.55 & -2.51 & 592.19 & 11.35 & - & - & 592.18 & 11.34 \\
\hline 2008 & 560.64 & 9.58 & 94.63 & 17.48 & 655.27 & 10.65 & - & - & 655.27 & 10.65 \\
\hline 2009 & 615.12 & 9.72 & 84.94 & -10.24 & 700.06 & 6.84 & 3.65 & & 703.71 & 7.39 \\
\hline 2010 & 766.5 & 24.61 & 102.74 & 20.95 & 869.24 & 24.17 & 6.07 & 66.13 & 875.31 & 24.38 \\
\hline 2011 & 815.81 & 6.43 & 115.7 & 12.62 & 931.51 & 7.16 & 7.84 & 29.26 & 939.35 & 7.32 \\
\hline 2012 & 828.86 & 1.6 & 103.97 & -10.14 & 932.83 & 0.14 & 7.09 & -9.56 & 939.92 & 0.06 \\
\hline 2013 & 820.47 & -1.01 & 98.87 & -4.19 & 919.34 & -1.45 & 3.83 & -45.88 & 923.17 & -1.78 \\
\hline 2014 & 921.25 & 12.28 & 97.91 & -0.96 & 1019.16 & 10.86 & 13.25 & 245.15 & 1032.41 & 11.83 \\
\hline 2015 & 976.5 & 6 & 95.5 & -2.46 & 1072 & 5.18 & 12.27 & -7.32 & 1084.28 & 5.02 \\
\hline 2016 & 1177.97 & 20.63 & 106.55 & 11.57 & 1284.52 & 19.82 & 14.71 & 19.83 & 1299.23 & 19.82 \\
\hline CAGR & & 10.12 & & 2.58 & & 12.70 & & 22.03 & & 9.34 \\
\hline
\end{tabular}

Tourist Arrivals are shown in Thousands. Data not compiled by source for Foreign Tourist Arrivals from 2006-2008

Table I shows the total tourist arrivals to AthirappillyVazhachal waterfalls, which is a prominent eco-tourism destination in Thrissur district of Kerala during the period 2006 to 2016. During the last eleven years, it can be observed that there is an increase in number of total arrivals annually but the annual growth rate of total tourist arrivals are uneven. In 2007 and 2008 the annual growth rate was around 10.00 per cent which rose to 24.38 per cent in 2010 which is the highest growth rate in the last eleven years. The annual growth rate declined to 7.32 per cent in 2011 and further reduced to 0.06 per cent in 2012 and in 2013 the total tourist arrivals in absolute figures where less than that of previous year and it was reflected as a -1.78 per cent decrease in 2013. The annual growth rate recovered its pace with 11.83 per cent in 2014 and there was only 5.02 per cent growth in 2015.The year 2016 marked the second highest annual growth in total tourist arrivals with a 19.82 per cent in the last eleven years. The compound annual growth rate of total tourist arrivals during the period is 9.34 per cent. During the last eleven years, it can be observed that there is an increase in number of domestic tourist arrivals annually but the annual growth rate of domestic tourist arrivals are uneven. In 2007 and 2008 the annual growth rate was around 10.00 per cent which rose to 24.61 per cent in 2010 which is the highest growth rate in the last eleven years. The annual growth rate declined to 6.43 per cent in 2011 and further reduced to 1.60 per cent in 2012 and in 2013 the total tourist arrivals in absolute figures where less than that of previous year and it was reflected as a -1.01 per cent decrease in 2013. The annual growth rate recovered its pace with 12.28 per cent in 2014 and there was only 6.00 per cent growth in 2015.The year 2016 marked the second largest annual growth in domestic tourist arrivals with a 20.63 per cent in the last eleven years. The compound annual growth rate of domestic tourist arrivals during the period is 10.12 per cent.

In the last eleven years, it can be observed that there is only positive annual growth rate during 2008 (17.48 per cent), 2010 (20.95 per cent), 2011(12.62 per cent) and 2016 (11.57 per cent). In all the other years, annual growth rate shows a declining trend with a maximum decline in 2009 (-10.24 per cent) and 2012 (-10.14 per cent). The maximum annual growth in student tourist arrivals are recorded in the year 2010 (20.95 per cent) and 2011 (12.62 per cent).The compound annual growth rate of student tourist arrivals for the last eleven years is 2.58 per cent.

The highest annual growth rate of foreign tourist arrivals can be observed in the year 2014 (245.15 per cent) and the highest decline in annual growth rate can be observed in 2013 (-45.88). The annual growth rate of foreign tourist 
arrivals is uneven for the last eight years. In the year 2015 there is a decline of -7.32 per cent in annual growth rate and in 2016 the annual growth rate recovered by 19.83 per cent. The compound annual growth rate of foreign tourist arrivals for the last eight years is 22.03 per cent.

\section{SEASONALITY OF TOURIST ARRIVALS AT ATHIRAPPILLY-VAZHACHAL}

The following section provides the monthly seasonality of domestic tourist arrivals, foreign tourist arrivals and total tourist arrivals to Athirappilly-Vazhachal Tourism Zone. The whole year is divided into three seasons based on the number of arrivals: The peak season or the season with highest number of tourist arrivals, the season with lowest number of tourist arrivals and the season with moderate number of tourist arrivals.

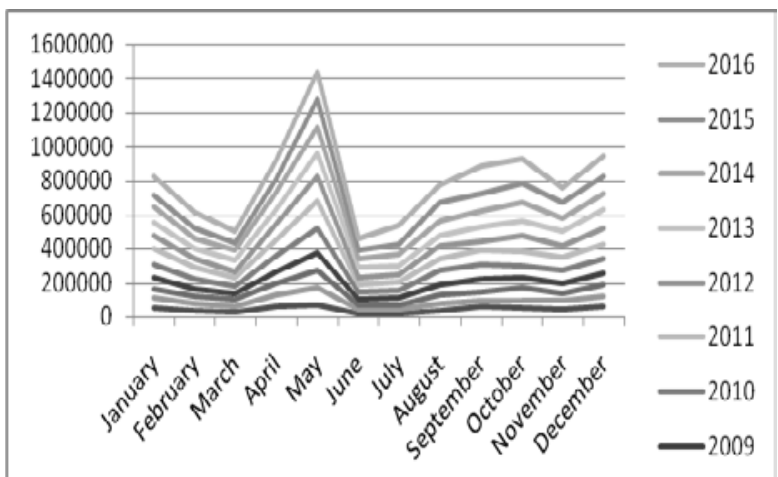

Fig 1 Month-Wise Seasonality of Total Tourist Arrivals to Athirappilly-Vazhachal

Figure 1 depicts the month-wise seasonality of total tourist arrivals to Athirappilly Vazhachal ecotourism destination during the 11 year period from 2006 to 2016. As it can be observed from the figure the peak season or the months in which there are high levels of total tourist arrivals are May, September, October and December. The least number of total tourist arrivals are during June, March, February and November. There is moderate number of total tourist arrivals during April, August, January and July. The total tourist arrivals is a total of domestic (adult) tourist arrivals, domestic (student) tourist arrivals and foreign tourist arrivals. The month wise seasonality of total tourist arrivals is dependent more on domestic (Adult) tourist arrivals and domestic (Student) arrivals as their share to the total tourist arrivals is more as compared to the share of foreign tourist arrivals.

Figure 2 depicts the month-wise seasonality of domestic (Adult) tourist arrivals to Athirappilly Vazhachal ecotourism destination during the 11 year period from 2006 to 2016. As it can be observed from the figure the peak season or the months in which there are high levels of domestic (Adult) tourist arrivals are April, May, September and October. The least number of domestic (Adult) tourist arrivals are during February, March, June and November.

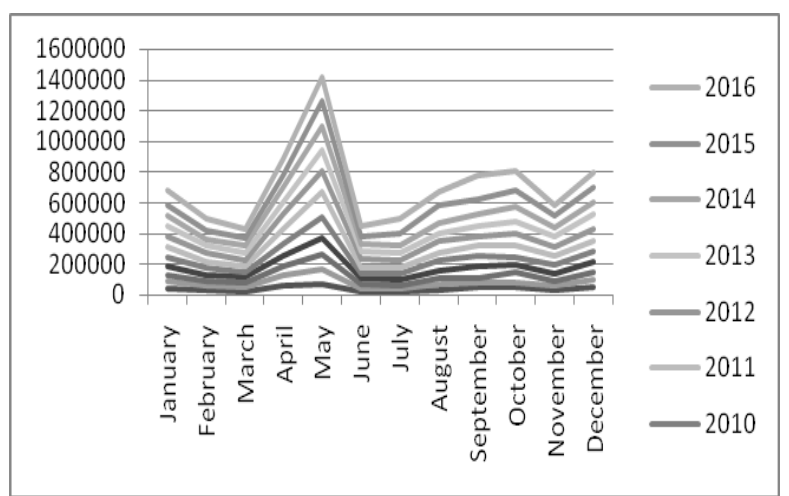

Fig 2 Month-Wise Seasonality of Domestic (Adult) Tourist Arrivals to Athirappilly-Vazhachal

There is moderate number of domestic (Adult) tourist arrivals during July, August, December and January. This trend could be observed from the chart depicted above. The high levels of Domestic (Adult) tourist arrivals during April, May, September and October may be due to summer vacation, Onam Vacation and Pooja Holidays. There is a drop in tourist arrivals during November which is compensated during December which may be due to the Christmas holidays. There are also high domestic tourist arrivals during the monsoon.

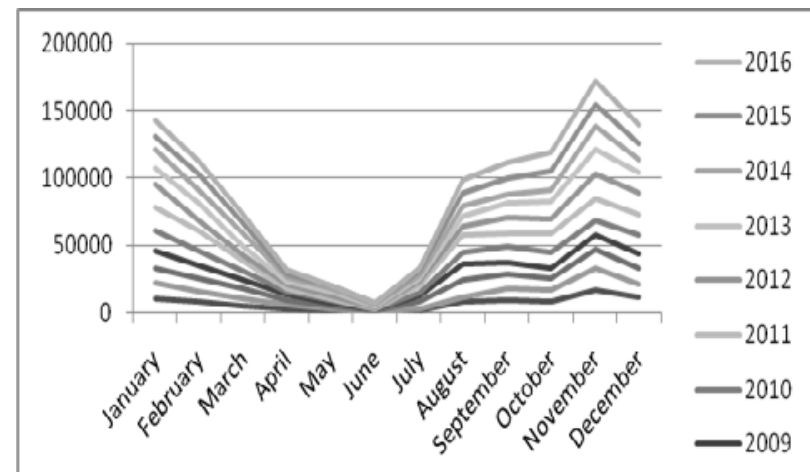

Fig 3 Month-Wise Seasonality of Domestic (Student) Tourist Arrivals to Athirappilly-Vazhachal

Figure 3 depicts the month-wise seasonality of domestic (Student) tourist arrivals to Athirappilly Vazhachal ecotourism destination during the 11 year period from 2006 to 2016. As it can be observed from the figure the peak season or the months in which there are high levels of domestic (Student) tourist arrivals are October, November, December and January. The least number of domestic (Student) tourist arrivals are during April, May, June and July. There is moderate number of domestic (Student) tourist arrivals during February, March, September and August. This trend could be observed from the chart depicted above. The high levels of Domestic (Student) tourist arrivals during October, November, December and January may be due to Annual one day tours that are done during the end of academic year before year end annual examinations in March. There are very less number of student tourist arrivals during April, May, June and July when the academic institutions are on summer vacation and during the opening period. 


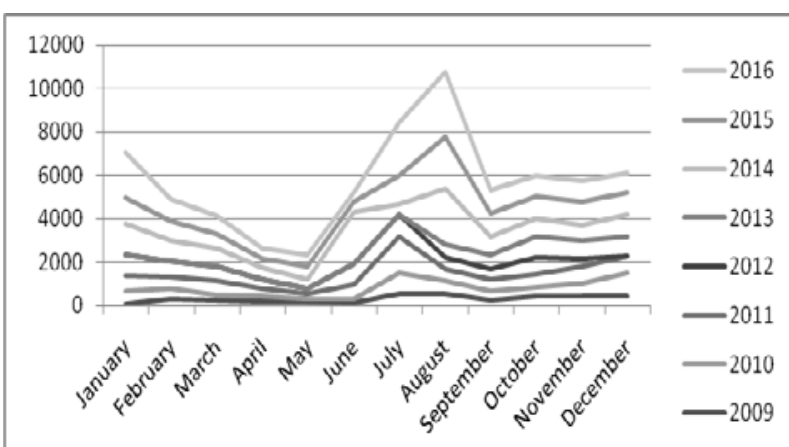

Fig 4 Month-Wise Seasonality of Foreign Tourist Arrivals to Athirappilly-Vazhachal

Figure 4 depicts the month-wise seasonality of foreign tourist arrivals to Athirappilly Vazhachal ecotourism destination during the 8 year period from 2009 to 2016. As it can be observed from the figure the peak season or the months in which there are high levels of foreign tourist arrivals are from July to September. The least number of foreign tourist arrivals are during February to June. There is moderate number of foreign tourist arrivals during October to January. This trend could be observed from the chart depicted above. The peak season (July - September) has many peculiarities and the most important among them is that the waterfalls which is the main attraction of this ecotourism destination will be more attractive during the monsoon. It is evident from the figure that the foreign tourist arrivals are increasing year by year.

Growth of tourist arrivals over years and seasonality are the most important considerations as an ecotourism destination is concerned. Growth of tourists indicates the tourism potential of the destination whereas seasonality provides the inference relating to the seasons when there will be high tourist traffic and thereby helps ecotourism management. As Athirappilly and Vazhachal ecotourism destinations are concerned it can be observed that the total tourist arrivals are increasing annually in absolute numbers but the growth rate of total tourist arrivals is uneven. It is to be specially mentioned that in year 2010 and 2016, the growth rate of total tourist arrivals show a spectacular increase. It was also observed that the compound annual growth rate of student tourist arrivals is less as compared to domestic and foreign tourist arrivals. The foreign tourist arrivals show a huge increase in the year 2014 and the compound annual growth rate of foreign tourist arrivals for last eight years is 22.03 percent which indicates the popularity and preference of ecotourism destination among international tourists.

Seasonality of the ecotourism destination is provided on the basis of tourist arrivals and the total tourist arrivals are largely affected by the domestic tourist arrivals and student tourist arrivals. Seasonality could be used as an effective tool by the ecotourism managers so that better revenue could be earned and better planning of destination shall be achieved thereby improving the quality of tourism experience to tourists as well as improving the economic benefits to the host community.

\section{FINDINGS OF THE STUDY}

\section{A. Tourist Arrival Growth at Athirappilly - Vazhachal Tourism Destination}

During the last eleven years, it can be observed that there is an increase in number of total arrivals annually but the annual growth rate of total tourist arrivals are uneven. In 2007 and 2008 the annual growth rate was around 10.00 per cent which rose to 24.38 per cent in 2010 which is the largest growth rate in the last eleven years. The annual growth rate declined to 7.32 per cent in 2011 and further reduced to 0.06 per cent in 2012 and in 2013 the total tourist arrivals in absolute figures where less than that of previous year and it was reflected as a -1.78 per cent decrease in 2013. The annual growth rate recovered its pace with 11.83 per cent in 2014 and there was only 5.02 per cent growth in 2015.The year 2016 marked the second largest annual growth in total tourist arrivals with a 19.82 per cent in the last eleven years. The compound annual growth rate of total tourist arrivals during the period is 9.34 per cent.

During the last eleven years, it can be observed that there is an increase in number of domestic tourist arrivals annually but the annual growth rate of domestic tourist arrivals are uneven. In 2007 and 2008 the annual growth rate was around 10.00 per cent which rose to 24.61 per cent in 2010 which is the largest growth rate in the last eleven years. The annual growth rate declined to 6.43 per cent in 2011 and further reduced to 1.60 per cent in 2012 and in 2013 the total tourist arrivals in absolute figures where less than that of previous year and it was reflected as a -1.01 per cent decrease in 2013. The annual growth rate recovered its pace with 12.28 per cent in 2014 and there was only 6.00 per cent growth in 2015.The year 2016 marked the second largest annual growth in domestic tourist arrivals with a 20.63 per cent in the last eleven years. The compound annual growth rate of domestic tourist arrivals during the period is 10.12 per cent.

In the last eleven years, it can be observed that there is only positive annual growth rate during 2008 (17.48 per cent), 2010 (20.95 per cent), 2011(12.62 per cent) and 2016 (11.57 per cent). In all the other years, annual growth rate shows a declining trend with a maximum decline in 2009 (-10.24 per cent) and 2012 (-10.14 per cent). The maximum annual growth in student tourist arrivals are recorded in the year 2010 (20.95 per cent) and 2011 (12.62 per cent).The compound annual growth rate of student tourist arrivals for the last eleven years is 2.58 per cent.

During an eight year period, the highest annual growth rate of foreign tourist arrivals can be observed in the year 2014 (245.15 per cent) and the largest decline in annual growth rate can be observed in 2013 (-45.88 per cent). The annual growth rate of foreign tourist arrivals is uneven for the last eight years. In the year 2015 there is a decline of -7.32 per cent in annual growth rate and in 2016 the annual growth rate recovered by 19.83 per cent. The combined annual 
growth rate of foreign tourist arrivals for the last eight years is 22.03 per cent.

\section{B. Seasonality of Tourist Arrivals At Athirappilly- Vazhachal}

When the month-wise seasonality of foreign tourist arrivals to Athirappilly Vazhachal ecotourism destination during the 8 year period from 2009 to 2016 is analysed, it can be observed that the peak season or the months in which there are high levels of foreign tourist arrivals are from July to September. The least number of foreign tourist arrivals are during February to June. There is moderate number of foreign tourist arrivals during October to January.

When the month-wise seasonality of domestic (Adult) tourist arrivals to Athirappilly Vazhachal ecotourism destination during the 11 year period from 2006 to 2016 is analysed it can be observed that the peak season or the months in which there are high levels of domestic (Adult) tourist arrivals are April, May, September and October. The least number of domestic (Adult) tourist arrivals are during February, March, June and November. There is moderate number of domestic (Adult) tourist arrivals during July, August, December and January.

When the month-wise seasonality of domestic (Student) tourist arrivals to Athirappilly Vazhachal ecotourism destination during the 11 year period from 2006 to 2016 is analysed it can be observed that the peak season or the months in which there are high levels of domestic (Student) tourist arrivals are October, November, December and January. The least number of domestic (Student) tourist arrivals are during April, May, June and July. There is moderate number of domestic (Student) tourist arrivals during February, March, September and August.

When the month-wise seasonality of total tourist arrivals to Athirappilly Vazhachal ecotourism destination during the 11 year period from 2006 to 2016 is analysed it can be observed that the peak season or the months in which there are high levels of total tourist arrivals are May, September, October and December. The least number of total tourist arrivals are during June, March, February and November. There is moderate number of total tourist arrivals during April, August, January and July.

Based on the monthly seasonality of tourist arrivals, the seasons could be categorized for providing quality tourism experience to various categories of tourists. This could be helpful for ecotourists as well as those who are engaged in ecotourism management so that proper plans can be made and carrying capacity considerations are adequately met.

\section{CONCLUSION}

The study aimed to provide a very brief elucidation on the growth pattern of tourist arrivals and monthly seasonality of tourist arrivals. The segmentation of tourists into domestic (adult) Tourists, domestic (student) tourists and foreign tourists and the separate growth and monthly seasonality study will help the process of tourist forecasts and proper planning of resources in order to meet the tourism demand. This study could provide the pattern of growth (tourist arrivals) and monthly seasonality of Athirappilly-Vazhachal ecotourism destination as it taken into account the tourist arrivals of the same ecotourism destination. For proper maintenance and development of ecotourism destinations, separate destination centric growth and monthly seasonality studies should be conducted so that annual management plans could be crafted efficiently. Community based ecotourism management is indispensable and forms the foundation for sustainable development. Community development is inevitable for improving the quality of life of community members, to protect and preserve their natural and cultural patrimony and to provide them with economic benefits. This process bridges the gap between community development and conservation of natural resources through sustainable economic growth. By the process of accrediting community for proper management of tourism destination through Community Based Ecotourism Management, restraints arising from unemployment, social frustration, and mismanagement of resources associated with management of ecotourism resources could be minimised. This requires a collaborative effort of Central and State Government, Forest and Wildlife Department, Department of Tourism, Non-Governmental Organizations, local administrative bodies and active involvement of educational institutions for the purpose of education, training and better development.

\section{SUGGESTIONS}

Based on the data provided by Kerala Forest Statistics 20092016, it was found that Vazhachal Territorial Division of Kerala Forest and Wildlife Department generates income from ecotourism activities more than any other ecotourism destination in Kerala. The destination is also connected to other tourism sites and there are amusement parks, resorts, lodges and restaurants near to Athirappilly-Vazhachal waterfalls owing to its tourism potential. It is high time that government should take appropriate measures to develop and widen the ecotourism potential through careful investments. If such kind of a well planned investment is made it would be more beneficial both in terms of additional revenue generation as well as development of living standards of the host community.

Based on the findings of the study, it was found that the total tourist arrivals, foreign tourist arrivals and domestic tourist arrivals to Athirappilly- Vazhachal are consistently increasing year after year. It is one of the highly visited ecotourism destinations in Kerala. There is huge tourist traffic during the peak seasons which results in traffic congestion on the way to destination and lack of adequate parking facility. If a master plan is made for this ecotourism destination after conducting proper feasibility studies by 
planning authorities it will improve the quality of destination and also benefit the residents.

\section{REFERENCES}

[1] Abraham, B. G., \& Rajasenan, D. (2015). Community Participation in Ecotourism: An Inclusive Development Option for Kerala (Doctoral dissertation, Cochin University of Science And Technology).

[2] Hudson, B. J. (1998). Waterfalls resources for tourism. Annals of Tourism Research, 25(4), 958-973.

[3] Ke, L. (2012). The weakness and innovation of China Ecotourism. Physics Procedia, 25, 953-957.
[4] Komppula, R., \& Komppula, R. (2016). The role of different stakeholders in destination development. Tourism Review, 71(1), 6776.

[5] Manoj, P .K. (2017). Impact of Ecotourism: Evidence from Thenmala Ecotourism Destination in Kollam District, Kerala. Asian Academic Research Journal of Multidisciplinary, 4, 42-53.

[6] Salpekar, A. (2009). Indian Tourism, Wildlife Tourism and Ecotourism. Jnanada Prakashan

[7] Wearing, S., \& Neil, J. (2009). Ecotourism: impacts, potentials and possibilities? Routledge.

[8] Weaver, D. B., \& Lawton, L. J. (2007). Twenty years on: The state of contemporary ecotourism research. Tourism management, 28(5), 1168-1179. 